\title{
Docile Bodies, Subjectivity and Self- Constitution in Women On The Edge of Time
}

\author{
Müge KARAYAYLALI BAYRAKTAR ${ }^{1}$ \\ Esma TEZCAN ${ }^{2}$
}

\begin{abstract}
Michel Foucault's concept of docile bodies, in Discipline and Punish, draws on the theory that the docile body is a pliable object, in that, when disciplinary force is enforced through control and dependency, the subject becomes bound to the structure of such disciplinary practices. According to Foucault, the docile body "is something that can be made; out of a formless clay, an inapt body [from which] the machine required can be constructed" (Foucault, 1978/2012, p. 135). Foucault, therefore, suggests that the docile body is suited to being "manipulated, shaped, trained" willingly (Foucault, 1978/2012, p.136). In this regard, he underlines the process of training, as it becomes a crucial facet of mechanics of power to impose its dominancy on the docile body. Upon analysing the settings where individuals are trained to become docile and profitable as required -in places such as schools, hospitals, prisons and mental institutions- Foucault concludes that, the purpose of such institutions is to create willingly obedient individuals, who respond to the designated task, which is given to maintain the status quo, through normalising and the internalisation of surveillance. As a result, through the making of "docile, useful body", as Foucault argues, "the body becomes a 'political field,' inscribed and constituted by power relations". (Deveaux, 1996). On the subject of resistance, a rather controversial subject for feminist agenda, Foucault argues "where there is power, there is resistance, and yet, or rather consequently, this resistance is never in a position of exteriority in relation to power" (Foucault, 1978, p. 95). The selected novel, namely Women On The Edge of Time (1976) by Marge Piercy, presents intriguing perspectives on the concept of power and speculates on women's agency regarding their
\end{abstract}

\footnotetext{
${ }^{1}$ Istanbul Aydin University, Istanbul,mugebayraktar@stu.aydin.edu.tr, https://orcid.org/0000-0003-2849-6768

2 Asst. Prof. Dr., Istanbul Aydin University, Istanbul, esmatezcan@aydin.edu.tr, https://orcid.org/0000-0002-5781-9119

Research Article - Submit Date: 03.11.2020, Acceptance Date: 27.01.2021

DOI: 10.17932/IAU.IJMCL.2015.014/ijmcl_v07i1003
} 
bodies by implying the fact that socio-political agendas shape not only the technology but also the fields of medicine and science, leading to the ultimate manipulation of the female body. In this regard, one aim of this article is to explore feminist reactions to Foucault's theories on body, power and sexuality. Then, by utilising these theories as analytical tools, this article also aims to examine the treatment and objectification of the protagonist in the narrative by medical facilities. Finally, the extent of which she is able to maintain the control of her subjectivity when faced with disciplinary forces as well as her integrity in society will be analyzed.

Keywords: Foucault, Docile Bodies, Women on the Edge of Time, Subjectivity, Sexuality, Power, Feminism

\section{ÖZ}

Michel Foucault'nun Disipline and Punish'teki uysal bedenler kavramı, uysal bedenin esnek bir nesne olduğu teorisine dayanır, bu nedenle disiplin gücü kontrol ve bağımlılık yoluyla uygulandığında özne bu tür disiplin uygulamalarının yapısına bağlı hale gelir. Foucault'ya göre, uysal beden "yapılabilen bir şeydir; biçimsiz bir kilden, gerekli makinenin yapılabileceği uyumsuz bir vücuttur" (Foucault, 1978/2012: 135). Bu nedenle Foucault, uysal bedenin isteyerek "manipüle edilmeye, şekillendirilmeye, eğitilmeye" uygun olduğunu öne sürer (Foucault, 1978/2012, p. 136). Bu bağlamda, Foucault uysal bedene egemenliğini empoze etmek için iktidar mekaniğinin çok önemli bir yönü haline geldiğinden, eğitim sürecinin altını çizer. Foucault, bireylerin gerektiği kadar uysal ve kârlı olmak için eğitildiği ortamları -okullar, hastaneler, hapishaneler ve akıl hastaneleri gibi- analiz ettikten sonra, bu tür kurumların amacının gözetimi içselleştirerek, statükoyu korumak amacıyla belirlenenlere yanıt veren istekli, itaatkâr bireyler yaratmak olduğu sonucuna varır. Sonuç olarak, Foucault'nun öne sürdüğü gibi, "uysal, kullanışlı beden" inşası yoluyla, "beden, iktidar ilişkileri tarafından yazılan ve oluşturulan bir" politik alan haline gelir (Deveaux, 1996). Foucault, feminist gündem için oldukça tartışmalı bir konu olan direniş konusunda, "iktidarın olduğu yerde direniş vardır, ancak daha doğrusu bu direniş asla iktidarla ilişkili olarak bir dişsallık konumunda değildir" (Foucault, 1978, p. 95). Marge Piercy'nin seçilen romanı, Zamanın Kıyısında Kadınlar (1976), sosyo-politik gündemlerin sadece teknolojiyi değil, aynı zamanda bilim ve tıp alanlarını da şekillendirdiği gerçeğini ima ederek, iktidar kavramı ve kadının kendi bedeni üzerindeki kontrolü hakkında ilginç bakış açıları sunarak, bunun, kadın vücudunun nihai manipülasyonuna yol açtığını belirtir. $\mathrm{Bu}$ bağlamda, bu makalenin amaçlarından biri, Foucault'nun beden, iktidar ve cinsellik üzerine kuramlarına feminist tepkileri incelemektir. Daha sonra, bu teorileri analitik araçlar olarak kullanarak, bu makale aynı zamanda anlatıda 
kahramanın tıbbi tesisler tarafından ele alınması ve nesneleştirilme sürecini de incelemeyi amaçlamaktadır. Son olarak, disiplin güçleri ile karşı karşıya kaldığında öznelliğinin kontrolünü ve toplumdaki bütünlüğünü ne ölçüde sürdürebildiği analiz edilecektir.

Anahtar Kelimeler: Foucault, Uysal Bedenler, Zamanın Kenarındaki Kadınlar, Öznellik, Cinsellik, Iktidar, Feminizm

\section{INTRODUCTION}

Michel Foucault is one of the few thinkers whose theorisation on the themes of subject, power and sexuality has immensely influenced contemporary feminist studies. His influence seems so palpable that even scholars who refute Foucault's claims are obliged to endorse his contributions to feminist theory. Today, even more than three decades after his death, Foucault's work still seems to ignite debates over the efficacy of his ideas on feminist theory. While proponents of postmodernism embrace Foucault's thoughts, as they eschew from normative and traditional notions of freedom as well as unity and rights, proponents of progressive politics oppose Foucault's postmodern understanding of body and power, claiming that it undermines the significance of emancipatory politics.

At this point, before exploring feminist reactions to Foucault, it seems appropriate for the framework of this article to begin with a concise overview of his work. His work may be divided into three phases: archaeological, genealogical, and ethical. Margaret McLaren posits that these phases "roughly correspond to a chronological order of early (archaeological), middle (genealogical), and late (ethical)" (McLaren, 2002, p. 3). To begin with, his archaeologies consist of The Birth of the Clinic (1963), The Order of Things (1966), and The Archaeology of Knowledge (1969). Archaeology is related to the method applied by Foucault during what is referred to as his early days. The archaeological approach centres on the limitations of thought and knowledge, as it interrogates the underlying foundations behind these norms to ultimately claim that specific types of knowledge can only be known in specific historical eras. For Foucault, these shifts in thought and knowledge are discursive, that is, they constitute and govern what is allowed to be said in any given time. Foucault names these discursive constructions "epistemes." As such, archaeology aims to analyse how new disciplines come to light and how shifts in understanding present themselves. In this regard, as McLaren puts, archaeology is "static" in its method since "it seeks simply to uncover the structures of rationality that make such shifts" (McLaren, 2002 , s. 3). In other words, Foucault, in this phase, does not generate any practice; instead, he emphasises the discursive facet of knowledge. Foucault's genealogical works, which include Discipline and Punish (1975) and The History 
of Sexuality Volume One (1976), on the other hand, address ruptures and discontinuities in histories and consequently defy the notion of progress. For instance, Foucault, in Discipline and Punish, underlines "the unscientificity of human sciences", as he casts doubt on the scientific quality of myriads of disciplines such as criminology, psychiatry, pedagogy and psychology (Visker, 1995 , p. 3). From this standpoint, Foucault, further defines the purpose of historical analysis as "exposing the unscientificity of science", and yet, for him, the real predicament is not the validity of sciences but, as Visker argues, it is "the understanding that the truth-effects of science are at the same time power-effects" (Visker, 1995, p. 3). Foucault elaborates on the effect of power on science by proposing the following:

It is undoubtedly the following kinds of question that would need to be posed: What types of knowledge do you want to disqualify in the very instant of your demand: 'Is it a science'? Which speaking discoursing subjects... do you then want to 'diminish' when you say: 'I who conduct this discourse am conducting a scientific discourse, and I am a scientist'? (1980, p. 85).

As it may be inferred from the excerpt, Foucault's genealogies raise questions regarding existing practices of science as well as the construction of metanarratives by institutions adopting the dubious discourse of science to exercise power. Accordingly, Foucault begins to conceptualise the idea of power in his genealogical work. His conception of power, as McLaren contends, "is not unilateral; it is not negative, and it is not possessed by an individual or group of individuals"; instead, he argues, power may be "productive and positive" as it is -in fact- "a relationship" not "a thing" (McLaren, 2002, p. 4). This conceptualisation of power, which is also known as the concept of "docile bodies", has been the centre of criticism by some feminist spheres even though it has been effusively celebrated by others. Foucault posits that historical changes in the seventeenth- and eighteenth-century in Europe have led to the disciplining of bodies dissimilarly than the days of the monarchy. He explains that the new system of control necessitated the best use of workers for the profit of the state. This new system also needed the obedience of its subjects, which was made possible through the integration of control systems such as schools, prisons and asylums. In the said institutions, Foucault argues, power was exercised as a discipline through techniques including surveillance, as the 'eye of power' in the disciplinary gaze which consequently turned individuals into docile bodies without agency (Foucault, 1978/2012). In other words, the advent of the modern era reflects a transformation from what Foucault calls "sovereign power" domination through the use of force- to "disciplinary power" - domination through constant monitoring and disciplining of populations (Foucault, 1978/2012). 
The third phase of Foucault's work, which is referred to as ethical work consists of the second and third volumes of The History of Sexuality series are entitled The Use of Pleasure and The Care of the Self respectively. These works include some essays and interviews with titles such as "On the Genealogy of Ethics: An Overview of a Work in Progress," "The Subject and Power," "The Ethics of Care for the Self as a Practice of Freedom," and "Technologies of the Self". These works mainly focus on subjectivity, as Foucault extrapolates on the possibility of the active constitution of the subject. In "Technologies of the Self", Foucault describes four technologies; the two which deal with the study of the sciences and linguistics are not included in this article. Analysing the technology of power and the technology of the self, on the other hand, seems plausible for the purpose of this study, as they focus on "the ways in which we relate ourselves to ourselves, to contribute to the forms in which our subjectivity is constituted and experienced " (Davidson, 1994, p. 119). Foucault argues that to contribute to our subjectivity and to move beyond the self, a meticulous self-examination is required. From this standpoint, Foucault insists on intersubjectivity as the core principle of ethics. He describes intersubjectivity as co-existence of self with others (Biesta, 1999). In other words, by finding consolation in others, Foucault demonstrates a way to "get free of oneself" (Bernauer \& Michael, 1994, p. 141). He further explains ethics as the "process in which the individual delimits that part of himself that will form the object of his moral practice, defines his position relative to the precept he will follow, and decides on a certain mode of being that will serve as his moral goal" (Foucault, 1986, pp. 26-28). Videlicet, Foucault sees selfconstitution as possible if the self is able to deconstruct the imposed structures of society upon them with the ultimate intention of ethical and aesthetic selftransformation. Although this conceptualisation of self appears in his late works, as McLaren puts it, when the work of his life is examined as a whole instead of separate phases, his theories may be read as "contributions" to "rethinking subjectivity", which has enabled many postmodern feminists, as in the case of Judith Butler, to develop theories regarding female subjectivity and its construction by society. (McLaren, 2002, p. 5).

Overall, in his archaeological works, he questions the subject of humanism by emphasising that the idea of unified subjectivity is elusive; in that, it is -in fact- a result of specific discursive constructions and linguistic practices. Foucault's genealogical works, on the other hand, deal with the notion of power regarding subjectivity. He contends that power is not something to be possessed; instead, it is exercised on individuals through norms, practices, and institutions. Finally, Foucault's ethical works address the issue of subjectivity explicitly; by asserting that active self-constitution is possible. All in all, Foucault declares the objective in his writings as: 
To create a history of the different modes by which, in our culture, human beings are made subjects. My work has dealt with three modes of objectification which transform human beings into subjects. For example, I have chosen the domain of sexuality-how men have learned to recognise themselves as subjects of "sexuality." Thus it is not power, but the subject, which is the general theme of my research" (Foucault, 1982, p. 778).

In this respect, it would not be wrong to articulate that the idea of subjectivity is central throughout his work, which is also a rather significant agenda of feminism.

\section{COMING TO TERMS WITH FOUCAULT: A FEMINIST QUEST}

Although Foucault did not set out to contribute to feminist theories, his work has challenged conventional ways of thinking about power and subjectivity so substantially that, his theories have become both a source of heated debate and have also provided an enhancement to the understandings of feminist thought regarding the construction of gender, body and sexuality. Therefore, in this section, the arguments of feminists identifying with progressive politics are explained in comparison to the claims of postmodernist feminists with the intent of reaching a more inclusive understanding of both sides.

Even though there has always been divergent approaches and positions to feminist theory, it seems appropriate to state that all of them are political. As Rosemary Tong explains, in Feminist Thought, feminist theory "is not one, but many, theories or perspectives and each feminist theory or perspective attempts to describe women's oppression, to explain its causes and consequences, and to prescribe strategies for women's liberation" (Tong, 1989, p. 1). Accordingly, despite distinctness, all feminist positions problematise women's subjugation and seek ways to liberate women from this subordination. From this standpoint, one reason why some feminists oppose postmodern approaches to feminism is that they think postmodernism may merely provide a discursive examination of social construction and that their approach lacks practicality. For instance, Martha Nussbaum, a contemporary liberal feminist, refutes Foucault's ideas on power by claiming that he has developed what she calls "the fatalistic idea that we are prisoners of an all-enveloping structure of power, and that real-life reform movements usually end up serving power in new and insidious ways" (Nussbaum, 1999, p. 38). In other words, she is concerned that the interpretations of Foucault may undermine the value of resistance and feminism's touch with material reality, as they may lead to a path of passivity instead of political activism. Nussbaum, further argues that Foucault's rejection of grand narratives, 
his scepticism on the conceptions of history lead to what she calls a "narrow vision of the possibilities for change" (Nussbaum, 1999, p. 40). To a large extent, as a liberal feminist Nussbaum's criticism centres on Foucault's view of power, his concept of subject as well as his rejection of norms.

In a similar vein, radical feminists, too, oppose Foucauldian notions mostly in terms of sexuality, as they celebrate the very concept of womanhood and the body. In this regard, according to Somer Brodribb, a radical feminist, "Foucault's theories of discourse and his theories of power both originate in a notion of selfconstructing structures and a conception of the social which has no notion of the individual" (Brodribb, 1992, p. 19) As it can be clearly understood from the quotation, Foucault's understanding of the subject threatens the notion of woman and individuality, which radical feminism depends on.

As for Marxist feminists, they perceive capitalism as the fundamental reason for women's oppression; in this sense, they refer to women's problems as inevitable consequences of capitalism and economic oppression. Foucault, on the other hand, overtly criticises Marxism for its solipsistic focus on the economy. Furthermore, he refutes the notion of historical progress which is highlighted in Marxism. Foucault also rejects Marxist understanding of economic base and superstructure. This is due to the fact that, for Foucault, power is mobilised and cannot be refined based on the notion of totality (Olssen, 2004). Marxist feminists, in return, contend Foucault's theories are not sufficient to explain class oppression and the subjugation of women. Hartsock, for instance, criticises Foucault's notion of power as "unable to account for pervasive, systematic asymmetries of power" (Hartsock, 1990, p. 158). Socialist feminists, similarly, adopt a Marxist understanding of the economy, yet they add the emphasis of sex to their framework (Tong, 1989). Socialist feminists claim that Marxist and feminist theories may help women overcome oppression, only when they are combined. Heidi Hartmann expresses the significance of this combination as such: "The categories of Marxism are sex-blind. Only a specifically feminist analysis reveals the systemic character of relations between men and women. Yet a feminist analysis by itself is inadequate because it has been blind to history and insufficiently materialist" (Hartmann, 1993, p. 191). As a result of this double emphasis on history and sex, socialists feminists share similar concerns with Marxist feminists regarding Foucault's theories, arguing that his focus on local institutions prevents the formation of a more general structural analysis. On that note, Seyla Benhabib, a socialist feminist, hints "The postmodernist position(s) may eliminate not only the specificity of feminist theory but question the very emancipatory ideals of the women's movements altogether" (Benhabib, 1987, p. 222). Suffice to say, she, too, highlights the fact that Foucault's notion of power does not leave any agency on the part of the subject for resistance. In this respect, Benhabib then adds: "For Michel Foucault, there is no history of the victims but 
only a history of the construction of victimisation. . f for Foucault every act of resistance is but another manifestation of an omnipresent discourse-power complex" (Benhabib, 1987, p. 222).

In this account of concerns regarding Foucault's theories from different feminist approaches, it is possible to discern some commonalities. These critics take one aspect of many Foucauldian concepts, such as his ideas on subjectivity, power or his rejection of grand narratives and evaluate his approach accordingly. On the whole, there are three areas of controversy which fracture the potential unity between feminism and Foucault according to these critics: Foucault's ideas on subjectivity for undermining the capacity of the subject to resist; his androcentric approach as he avoids focusing on gender and female experiences; and finally, his notion of power as it cannot explain prevalent, systematic imbalances of power globally.

On the other hand, proponents of postmodernism, who embrace Foucault's theories to a great extent, defend them by developing several counter- arguments. To exemplify, for Sawicki, assuming the subjugation of women as merely a result of patriarchal social structures is "an oversimplified conception of power relations". He further states that Foucault's theory on power, instead, suggests power cannot be owned, but it can be exercised and it "circulates throughout the social body" (Sawicki, 1998, p. 164). Therefore, such an understanding of power, for Sawicki, has paved the way for feminists to analyse how women's selfunderstanding is constructed in relation to institutions which they are seeking to alter, rather than merely accusing patriarchy for owning power over women. Additionally, Foucault's redefinition of the relationship of subjects with power changed feminist understanding when he wrote: "Power is everywhere; not because it embraces everything, but because it comes from everywhere".

Nevertheless, he still attributes agency to individuals, as can be inferred from his response to a question concerning how freedom may even be possible if power is everywhere. Foucault answers the question as such: "If there are relations of power in every social field, this is because there is freedom everywhere. Of course, states of domination do indeed exist. In a great many cases, power relations are fixed in such a way that they are perpetually asymmetrical and allow an extremely limited margin of freedom" (Foucault, 1988, p. 1). As it can be seen from the excerpt, although Foucault articulates an "extremely limited margin of freedom", he does not rule out the possibility of resistance and mentions several forms of it: "violent resistance, flight, deception, strategies capable of reversing the situation" (Foucault, 1988, p. 12). Accordingly, Foucault's formalisation of power and resistance lead postmodern feminists to seek local reversals of power rather than a universally emancipatory one. 
Regarding the accusation of subjectivity, postmodern feminists argue that in his late work, Foucault revises his theoretical mindset to turn it into a more profitable project in the sense of providing more coherent politics. In a similar vein, Sawicki acknowledges that Foucault's later work on ethics "offers a more affirmative alternative to his earlier emphasis on the reactive strategy of resistance to normalisation" (Sawicki, 1998, p. 104). As mentioned before, Foucault has been accused of being androcentric and criticised for his approach on gender. At this point, postmodern feminists like Judith Butler draws on Foucault's work and argues that it provides a novel perspective for feminists to deconstruct the strictness of identity politics. She argues that:

The premature insistence on a stable subject of feminism, understood as a seamless category of women inevitably generates multiple refusals to accept the category. These domains of exclusion reveal the coercive and regulatory consequences of that construction, even when the construction has been elaborated for emancipatory purposes. Indeed, the fragmentation within feminism and the paradoxical opposition to feminism from "women" whom feminism claims to represent the necessary limits of identity politics. (Butler, 1990, p. 4)

Seen in these terms, Butler seems to seek for an escape from naturalised female identity as, for her, insisting on the category of women, far from enabling an emancipatory cause, leads to the exclusion of those who do not identify themselves in relation to that identity. Butler also criticises liberal feminist approaches as they defend universal feminist identity politics that may appeal "to a fixed 'feminist subject,' 'presumes, fixes and constrains the very 'subjects' that it hopes to represent and liberate" (Butler, 1990, p. 148). Moreover, for Butler, Foucault's understanding of identity, unlike other feminist theories, enables feminists to ponder upon positions that are not fixed or essential. According to Butler, one advantage of Foucault's concept of constituted self is that it paves the way for feminism to "politicise the processes through which stereotypical forms of masculine and feminine identity are produced" (Butler, 1990, p. 33).

All in all, despite not having any interest in gender and receiving criticism from some feminist spheres, Foucault, seems to have offered new perspectives for feminist thought to understand the ways sexuality, identity and the body are controlled by also highlighting the possibility of resistance and social construction through deconstructing historical impositions on the self. In this respect, as a final thought on the much-heated debate concerning the usefulness of Foucauldian notions for feminist thought, Caroline Ramazanoglu poignantly states: "Feminists cannot afford to ignore Foucault, because the problems he addresses and the criticisms he makes of existing theories and their political 
consequences identify problems in and for feminism" (Ramazanoglu, 1993/2003, p. 3).

\section{A FOUCAULDIAN ANALYSIS: WOMAN ON THE EDGE OF TIME}

As has been stated earlier, this article aims to examine the treatment and objectification of the protagonist in Piercy's Woman on The Edge of Time by several institutions and the process of self-constitution by utilising Foucault's theories on power, body and subjectivity. The novel presents an intriguing commentary concerning the position of marginalised women, by questioning their agency and subjectivity in the face of technologies and disciplines exercising power both in dystopian and utopian contexts. The narrative, in this sense, shares an aforementioned feminist scepticism on acknowledging Foucault's theories specifically on power and the subject by providing polarised perspectives about the issues of agency, resistance and total emancipation.

Piercy presents the arduous life of Connie Ramos to the reader. She is a secondgeneration Mexican woman living in New York in 1976. Throughout her life, she has been oppressed sexually and racially. The fact that she lives in poverty adds another dimension to her double burden. She has also been a victim of violence by the men in her life both psychologically and physically.

Moreover, as she is unemployed and uneducated, she is financially dependent on the men who abuse her. As a consequence of her miserable life, Connie develops a drinking problem which leads to violent behaviour on one occasion. Later on, in an attempt to protect her niece, Dolly, from her "pimp" Geraldo, Connie resorts to violence again. Her act of violence is not seen as self defence by the judge; thus, he finds her guilty and decides to send her to a mental hospital. Moreover, her only daughter is taken away from her on the grounds of being an unfit mother due to her diagnosis as mentally ill. In a sense, while critical decisions are being made about her, Connie has been silenced, as Connie is not even allowed to explain her own medical situation. The narrator depicts this as such:

Man to man, pimp and doctor discussed her condition, while Dolly sobbed. The doctor asked her only her name and the date. First, she said it was the fourteenth and then she changed it to the fifteenth, thinking it must be after midnight. She had no idea how long she had been unconscious. (Piercy, 1976, p. 13)

Moreover, when Connie is admitted to hospital, her identity papers are taken from her in return for a "plastic identification bracelet sealed on her wrist" (Piercy, 1976, p. 15). During her time in the hospital, she gradually perceives that the authorities of the hospital celebrate and reward normative feminine behaviour. 
Connie explains it as such: "The pressure was to say please and put on lipstick and sit at a table playing cards, to obey and work for nothing, cleaning the houses of the staff. To look away from graft and abuse. To keep quiet as you watched them beat other patients" (Piercy, 1976, p. 145). The violence represented in the narrative regarding the hospital does not end here; in the institution, the doctors experiment on Connie by inserting electro transmitters in her brain under the guise of helping her to keep violent thoughts under control.

From a Foucauldian perspective, the novel presents a modern society in which the reader observes several disciplinary techniques, which produce "knowledge", such as the court and the mental institution. In these institutions, as Foucault suggests, "power operates from the bottom up", (1976, p. 94) which means that power is a network including local exchanges. For instance, although Geraldo is a "pimp", the court rules in his favour, as he entails a superior rank on the disciplinary hierarchy of the society when compared to Connie who is a poor, marginalised woman. Ironically, Connie is institutionalised for being violent, while all the violence that has been imposed on her throughout her life goes unnoticed by the court, just like her act of sacrifice to protect another marginalised woman, Dolly. In a Foucauldian sense, therefore, it is possible to argue that the reader observes the role of power in producing the truth. According to Foucault, power cannot be manipulated or abused by "someone else". Instead, it is reinforced by every part of society, through "the types of discourse which [each society] accepts and makes function as true" (1980, p. 131). In this sense, Connie's consent on receiving the experimental treatment seems to be a result of the discourse labelling the medical field as "true". Also, the doctors' control over the thoughts of Connie further illustrates how the agency is taken away from her through the monitoring of her thoughts even before she acts upon them, which turns her into a docile body. Similarly, confiscating Connie's identity papers and giving her just a bracelet instead, may be read as the first step of constructing identity, as patients are eventually made to forget who they are in time. As can be inferred from Connie's remarks on femininity, the mental hospital represented in the novel may be an example of institutions adopting, what Foucault regards, a "dubious discourse of science" to exercise power. According to Foucault, scientific institutions manage to discipline bodies in several ways. As for the case of Connie, discipline is exercised by normalising "useful" behaviour, as well as by exercising repressive power to intercept agency ultimately.

Connie Ramos, then, stuck in a mental institution, telepathically transports to a futuristic society called Mattapoisett, with the help of Luciente, who is a resident of that society. This society does not, in any way, resemble Connie's society as it offers its citizens an ecologically sustainable and just life which is made possible through a revolution regarding reproductive technologies. Piercy's utopian society embraces the utilisation of techno-scientific tools to liberate women. As 
a result of such technology, birth is taken outside the female body, paving the way for mothers to be equal with fathers. Such technology radically transforms the values of society and almost eradicates the notion of gender for both women and men. In Piercy's utopian society, the women are not reduced solely to their ability to reproduce and neither do they experience the physical disadvantages of being pregnant. The men, in a similar vein, assume the responsibility of the child in a way that has never been socially acceptable before such technological advancement, as they are now able to bond with their children through breastfeeding, too. Furthermore, in Mattapoisett, the purpose of technology and science are determined, just like all policies, by the residents with transparency. As each resident participates in the decision- making process, the possibility of one group to dominate another is eliminated. In this sense, Mattapoisett is introduced as a post-hierarchy, post-gender society, where violence cannot be traced.

Here, Piercy seems to agree with Foucault that change in power relations can only be possible by altering the discourse of institutions. Moreover, it is possible to state that the new reproductive technology represented in the narrative, constitutes what Foucault calls an episteme shift, as it revolutionises the entire society by transforming what is known. The fact that such transformation is reached through the elimination of sexual difference in Piercy's utopian society can be considered as an extension of feminist agenda. This overlaps with the Foucauldian understanding of subjectivity as construction. In this regard, it is possible to argue that when the residents in the utopian society were freed from the discursive constructions of gender, they were able to produce politics outside of a fixed essence, which also changed the division of labour and the social structure of the society. However, the ideal society Piercy presents is -from a Foucauldian perspective- at an impasse for its emphasis on emancipation from all kinds of power. For Foucault, as discussed earlier, the disciplinary network does not take its source from capitalism or any other singular source. In this regard, for Foucault, even when capitalism is eradicated from the globe as in the case of Mattapoiset, power continues to be "self-reinforcing". It contains "internal intelligibility", as he insists "no one can be outside of power" (1980, pp. 141142). On that note, throughout the narrative, Piercy does not mention what happens if a woman chooses to give birth naturally for the sake of having that experience. Thus, it is possible to infer that to prevent such incidents; there may be a kind of intervention on women's body in Mattapoisett, which may be considered as an example of the invasiveness of technology as Foucault contends all technologies are.

Furthermore, even though Mattapoiset seems to be a transparent and harmonious society, the community is eventually polarised on the utilisation of reproductive technology. On the one hand, "mixers" defend the screening of only defective 
genes and maintaining an integrated gene pool. On the other hand, "shapers" favour genetic intervention to create useful traits through selective breeding (Piercy, 1976, p. 171). Luciente, as a mixer, believes that the notion of selective breeding may lead to a "power surge", which in turn might bring about hierarchical structures within the society. Subsequently, Connie, while trying to reach Luciente, ends up in another alternative future where technology has transformed human life radically in a negative way. In this future, the reader is introduced to a woman called Gildina, living in a "segregated and guarded" (217) apartment in New York as a sex slave. This future is presented as totalitarian, sexist and hierarchal. Piercy emphasises that such a totalitarian future may be possible if Connie and Luciente do not resist oppressive domination systems in their present.

Even though Piercy depicts an idealistic and utopian society, she deems it necessary to underline the unrest within it. For Foucault, such unrest is inevitable as he perceives power to be "something which is performed, something more like a strategy than a possession" (Mills, 2003, p. 34). From this standpoint, it can be argued that although the people of Mattapoiset do not claim to have power over each other, they internalise it and use it as a strategy in a non-repressive way to create bodies that they believe to be more "beneficial" for the sake of their community. For Foucault, this constitutes one of the myriad forms of relations of power. Therefore, it seems plausible to assert that Mattapoiset -an ideal, utopian society- founded initially to resist normalisation, ironically, creates its own Foucauldian "docile bodies".

All in all, Connie, who has been oppressed and abused multiple times in her life, decides to resist and make a difference after experiencing the sorrowful universe of Gildina. In an act of retaliation, she poisons six doctors, who she believes to be responsible for many abusive treatments on patients. She, then, boastfully states: "I murdered them dead. Because they are the violence prone. Theirs is the money and the power, theirs the poisons that slow the mind and dull the heart. Theirs are the powers of life and death. I killed them because it is war" (Piercy, 1976, p. 282).

\section{CONCLUSION}

Foucault's notion of power is based on the premise that there has always been a dynamic web of relations, exercised by every social organism in society, making it impossible for individuals to remain aloof. These institutions, Foucault posits, dominate and discipline populations through constant monitoring, which consequently turns them into docile bodies without agency (Foucault, 1978/2012). Foucault's description of power as ineluctable, however, is criticised 
by liberal, radical and Marxist feminists mainly for challenging the emancipatory agenda of feminist thought and undermining the capacity of the subject to resist.

Even though Foucault is criticised by these feminist spheres, his work on power, subjectivity and sexuality has provided feminist thought with novel theories on the female experience. Also, his theories have proven to be advantageous specifically for postmodern feminists, regarding their potential for developing politics. His understanding of power, for instance, has deconstructed the traditional understanding of the self and enabled women to perceive subjectivity in relation to institutions (Butler, 1990). This understanding of constituted subjectivity influenced several postmodern feminists like Judith Butler to oppose fixed or essential categories of women, which entirely altered identity politics for women. Additionally, in his later works, Foucault redefines the relationship of subjects with power by claiming that local reversals of power are possible (Foucault, 1988, p. 1). This recent definition has changed the agenda of postmodern feminists, as they began seeking local reversals of power rather than a universally emancipatory one (Sawicki, 1998, p. 164).

From this standpoint, although it seems that coming to terms with Foucault has never been a facile task for some strands of feminism, as explored earlier, this article argues that Foucault's conceptualisation of power, subjectivity and body may present crucial theoretical tools for feminists to analyse changing discourses regarding power, norms, identity along with the idea of subjectivity in society to ultimately contribute to the feminist agenda. In the light of this view, the aim of this paper was to analyse Piercy's Women on The Edge of Time considering Foucauldian concepts of power, docile bodies and self-constitution. Upon such examination, this article finally concludes that the protagonist, Connie, is not only a docile body who is victimised by disciplinary technologies but also proves to be a subject with the capacity to resist after going through what Foucault calls self-constitution. In this sense, it is possible to argue that Connie, just like Foucault has declared, is able to deconstruct the historical impositions made on her body through her experiences in two alternative universes. Furthermore, her realisation in the end of the novel can be read as a result of what Foucault calls "intersubjectivity". In other words, just like Foucault suggests, Connie seems to find consolation in the company of other female friends living in parallel universes, which helps her maintain her sanity in the institution. Accordingly, at the end of the book, she is able to fight back by murdering abusive doctors and having done this, feels liberated for it. However, it should be noted here that Connie merely succeeded to survive under the harsh conditions of the hospital. As such, it seems unlikely that her position as a poor and marginalized woman will change in the eyes of the society, which can also be read in alignment with Foucault, on the grounds of his claim concerning the impossibility of total emancipation of power. Nevertheless, as Foucault posits, it does not mean "one 
is trapped and condemned to defeat no matter what" (1980, p. 141). Instead, it seems that- just like Foucault suggests- the battle of resistance and power will continue to co-exist in every society, at any given time. This was clearly the case for Connie who, regardless of her albeit violent actions to reverse the status quo, was not able to do so.

\section{REFERENCES}

Benhabib, S. (1987). The Generalised and the Concrete Other: The KohlbergGilligan Con- troversy and Moral Theory. In K. D. Eva Feder (Ed.), Women and Moral Theory. New Jersey: Rowman \& Littlefield Publishers.

Bernauer, J. \& Michael, M. (1994). The ethics of Michel Foucault. In G. Gutting (Ed.), The Cambridge Companion to Foucault (pp. 141-156). Cambridge: Cambridge University Press.

Biesta, G. J. (1999). Radical intersubjectivity: Reflections on the "different" foundation of education. Studies in Philosophy and Education, 4(18), 203-220.

Brodribb, S. (1992). Nothing Mat(t)ers: A Feminist Critique of Postmodernism. North Melbourne: Spinifex Press.

Butler, J. (1990). Gender Trouble: Feminism and the Subversion of Identity. New York: Routledge.

Davidson, A. (1994). Ethics as ascetics : Foucault, the history of ethics, and ancient thought. In G. Gutting (Ed.), The Cambridge Companion to Foucault (pp. 115-135). Cambridge: Cambridge University Press.

Deveaux, M. (1996). Feminism and Empowerment: A Critical Reading of Foucault. (S. Hekman, Ed.) Feminist Epistemologies.

Foucault, M. (1977-78/2007). Security, territory, population: lectures at the Collège de France. Springer.

Foucault, M. (1978). The History of Sexuality vol 1, An Introduction, trans. Robert Hurley. New York: Pantheon.

Foucault, M. (1978/2012). Discipline and punish: The birth of the prison. Vintage. 
Foucault, M. (1980). Selected Interviews and Other Writings 1972-1977. (C. Gordon, Ed., C. Gordon, L. Marshall \& K. Soper, Trans.) New York: Pantheon Books .

Foucault, M. (1982). The Subject and Power. Critical Inquiry, 8(4), 777-795.

Foucault, M. (1986). The use of pleasure. In The history of sexuality (R. Hurley, Trans., Vol. 2). New York: Vintage Books .

Foucault, M. (1988). The Ethic of Care for the Self as a Practice of Freedom. In J. Bernauer, \& D. Rasmussen (Eds.), The Final Foucault (J. Gauthier, Trans.). Cambridge: MIT Press.

Hartmann, H. (1993). The Unhappy Marriage of Marxism and Feminism: Towards a More Progressive Union. (A. Jaggar, \& P. Rothenberg, Eds.) Feminist Frameworks.

Hartsock, N. (1990). Foucault on Power: A Theory for Women? In L. Nicholson (Ed.), Feminism/Postmodernism. New York : Routledge.

McLaren, M. (2002). Feminism, Foucault, and Embodied Subjectivity. New York: State University of New York Press.

Nussbaum, M. C. (1999). The Professor of Parody: The Hip Defeatism of Judith Butler. New Republic, 37-45.

Olssen, M. (2004). Foucault and Marxism: Rewriting the Theory of Historical Materialism. Policy Futures in Education, 2(3), 454-482.

Piercy, M. (1976). Women on The Edge of Time. Random House.

Ramazanoglu, C. (Ed.). (1993/2003). Up Against Foucault: Explorations of some tensions between Foucault and feminism. New York: Routledge.

Sawicki, J. (1998). Feminism, Foucault and "Subjects" of Power and Freedom. In J. Moss (Ed.), The Later Foucault: politics and philosophy. London : Thousand Oaks: Sage Publications.

Tong, R. (1989). Feminist Thought: A Comprehensive Introduction. Boulder: Westview Press.

Visker, R. (1995). Michel Foucault: Genealogy as Critique. (C. Turner, Trans.) Verso . 